\title{
Enzymatic Production of Protein Hydrolysates from \\ Steelhead (Oncorhynchus mykiss) Skin Gelatin as Inhibitors of Dipeptidyl-Peptidase IV and Angiotensin-I converting Enzyme
}

\author{
Imelda W.Y. Cheung and Eunice C.Y. Li-Chan* \\ The University of British Columbia, Faculty of Land and Food Systems, \\ Food Nutrition and Health Program, 2205 East Mall, \\ Vancouver, British Columbia, V6T 1Z4, Canada
}

*Corresponding author:

Eunice C.Y. Li-Chan, The University of British Columbia, Faculty of Land and Food Systems, Food Nutrition and Health Program, 2205 East Mall, Vancouver, British Columbia, V6T 1Z4, Canada

Telephone: 1 604-822-6182. Fax: 1 604-822-5143.

E-mail: Eunice.Li-Chan@ubc.ca 


\section{ABSTRACT}

The objective of this study was to generate protein hydrolysates with dual in vitro inhibitory activities against dipeptidyl-peptidase IV (DPP-IV) and angiotensin-I converting enzyme (ACE), by proteolytic enzymes acting either individually or sequentially on steelhead skin gelatin. The results showed strong dual bioactivity in the low molecular weight $(<3 \mathrm{kDa})$ fractions obtained by ultrafiltration of hydrolysates produced using the enzymes pepsin, CorolaseN or papain. Alternatively, unfractionated hydrolysates exhibiting high ACE and DPP-IV inhibitory activities as well as yields could be attained by strategic selection of two enzymes for successive hydrolysis of gelatin. In particular, hydrolysates produced using $4 \%$ papain for $2 \mathrm{~h}$ followed either by

ultrafiltration or by a second hydrolysis with $1 \%$ CorolaseN for $2 \mathrm{~h}$, presented potent dual activity as ACE and DPP-IV inhibitors, and should be investigated further as potential functional food ingredients or nutraceuticals for the management of hypertension and diabetes.

Key words: gelatin hydrolysate; enzymatic hydrolysis; dipeptidyl-peptidase IV inhibitory activity; angiotensin-I converting enzyme inhibitory activity; ultrafiltration 


\section{Introduction}

According to the World Health Organization (WHO), 422 million people worldwide were diagnosed with diabetes in 2014 and it is estimated that diabetes will become the $7^{\text {th }}$ leading cause of death in 2030 (WHO, 2016a). Diabetes and hypertension are linked, in that individuals with type 2 diabetes have higher incidence of hypertension than age-matched non-diabetic subjects and conversely, individuals diagnosed with hypertension are at higher risk of developing diabetes than those with normal blood pressure (Grossman \& Messerli, 2008). Furthermore, hypertensive diabetic patients face increased risk for various complications including left ventricular hypertrophy, coronary artery disease, decreased renal function, and accelerated development of diabetic retinopathy, and it has been reported that the combination of hypertension and type 2 diabetes significantly raises a person's risk of premature death (Campbell et al., 2011; Grossman \& Messerli, 2008; Lago, Singh \& Nesto, 2007). In fact, cardiovascular disease causes 17.5 million deaths annually, constituting $31 \%$ of all deaths worldwide (WHO, 2015) while diabetes accounted for 1.5 million deaths in 2012 (WHO, 2016a).

In view of the high occurrence and mortality rates associated with diabetes and cardiovascular disease, management of underlying metabolic conditions including high blood glucose (hyperglycemia) and high blood pressure (hypertension) is crucial, and is usually addressed through pharmacotherapy. Medicines to manage high blood pressure such as thiazides, ACE inhibitors or beta blockers are commonly prescribed concurrently with diabetic drugs such as metformin and dipeptidyl peptidase IV (DPP-IV) inhibitors to reduce the risk of cardiovascular disease (WHO 2016b). 
Over the last two decades, food-derived bioactive peptides have garnered much attention for their potential to serve as natural alternatives or complements to synthetic drugs. In particular, peptides isolated from various food sources that could contribute to the regulation of blood pressure by inhibiting angiotensin I-converting enzyme (ACE; EC 3.4.15.1) in vitro and/or exerting an antihypertensive effect in vivo are probably the most extensively studied category of food-derived bioactive peptides (Iwaniak, Minkiewicz \& Darewicz, 2014). More recently, peptides derived from food have been reported with in vitro and in vivo inhibitory activity against dipeptidyl peptidase IV (DPP-IV; EC 3.4.14.5), an enzyme that inactivates incretin hormones associated with insulin secretion and glycemic regulation (Lacroix \& Li-Chan, 2016; Power, Nongonierma, Jakeman \& FitzGerald, 2014). However, only a few studies have looked at simultaneous production of ACE and DPP-IV inhibitory activities by hydrolysis of food protein sources, namely canary seed protein (Estrada-Salas, Montero-Morán, Martínez-Cuevas, González \& Barba de la Rosa, 2014), egg yolk protein (Zambrowicz et al., 2015) and whey protein (Babij, Dąbrowska, Szołtysik, Pokora, Zambrowicz \& Chrzanowska, 2014; Lacroix, Meng, Cheung \& Li-Chan, 2016).

Potent ACE inhibitory peptides are usually 2 - 12 amino acids in length; amino acid residues such as Pro and Phe are favorable at the C-terminal while Ala and Val are preferred at the antepenultimate position (Iwaniak et al., 2014). DPP-IV inhibitory peptides are usually 2 - 7 amino acids long, and Pro or Ala have been shown to be important at the penultimate position of the N-terminus (Power et al., 2014). Since the amino acid residue Pro seems to be important in peptides displaying ACE as well as DPP-IV inhibitory activities, gelatin with its well-known repeating protein sequence 
comprising hydroxyproline (Hyp), Pro and Gly (Boran \& Regenstein, 2010) may potentially be a very promising substrate for production of peptides with both of these properties. Moreover, collagen, the starting material for preparing gelatin, can be extracted from fish skin, which is largely available as marine processing by-products at no or low cost (Pal \& Suresh, 2016).

Indeed, several studies have reported the production of various fish skin gelatin hydrolysates with either ACE inhibitory activity or DPP-IV inhibitory activity using various proteolytic enzyme preparations and processing conditions. For example, to produce ACE-inhibitory peptides, Byun and Kim (2001) used a three-step recycling membrane reactor for consecutive hydrolysis of Alaska pollack skin gelatin with Alcalase, pronase $\mathrm{E}$ and collagenase, and reported that peptides of $0.9-1.9 \mathrm{kDa}$ in size were responsible for the ACE-inhibitory activity. Mahmoodani, Ghassem, Babji, Yusop \& Khosrokhavar (2014) also used Alcalase followed by ultrafiltration to produce ACEinhibitory peptides in the lower molecular weight fractions. Ngo, Ryu \& Kim (2014) reported that among four proteases (Alcalase, Protamex, Flavourzyme and Neutrase) investigated for hydrolysis of skate skin gelatin, Alcalase produced the hydrolysate exhibiting highest ACE-inhibitory activity. Similarly, in a study comparing Alcalase, Pronase E, pepsin and trypsin for hydrolysis of Nile tilapia skin gelatin, Vo, Ngo, Kim, Ryu \& Kim (2011) reported highest ACE-inhibitory activity for the hydrolysate produced with Alcalase. In contrast, Choonpicharn, Jaturasitha, Rakariyatham, Suree \& Niamsup (2015) reported no significant differences in the ACE inhibitory activity between hydrolysates produced from Nile tilapia skin gelatin using bromelain, papain, trypsin, Flavourzyme, Alcalase or Neutrase under the same conditions used by Vo et al. (2011), 
suggesting that Alcalase was not any more effective than the other proteases.

Furthermore, Khiari, Rico, Martin-Diana \& Barry-Ryan (2014) used 1\% pepsin for up to $24 \mathrm{~h}$ for hydrolysis of mackerel skin gelatin to produce ACE-inhibitory and antithrombotic peptides, while Lassoued, Mora, Barkia, Aristoy, Nasri \& Toldrá (2015) reported that stronger ACE-inhibitory activity was produced from thornback ray skin gelatin hydrolysates by a protease isolated from a marine Bacillus subtilis (B. subtilis A26) than by the commercial product Neutrase ${ }^{\circledR}$, a metalloprotease from $B$. amyloliquefaciens.

Only a few studies have been reported to date on the conditions for producing DPP-IV inhibitory hydrolysates from fish skin as the starting material. Li-Chan, Hunag, Jao, Ho \& Hsu (2012) concluded that higher DPP-IV inhibitory activity could be obtained from Atlantic salmon skin gelatin using Flavourzyme than either Alcalase or bromelain. Similarly, in a study comparing several commercial enzyme preparations (Alcalase, Flavourzyme, bromelain, pepsin, trypsin and chymotrypsin) for the hydrolysis of gelatin extracted from the skin of different cold and warm water fish, highest DPP-IV inhibitory activity was found for the hydrolysates produced by the action of 5\% Flavourzyme for up to 8 hrs (Wang, Hsieh, Hung, Jao, Chen \& Hsu, 2015). On the other hand, Sila et al. (2015) found no significant difference in $\mathrm{IC}_{50}$ values between hydrolysates produced from barbel skin gelatin by seven of eight different commercial proteases tested using 10\% (w/w) enzyme. Similarly, Protease XXIII from Aspergillus melleus and Orientase 90N from Bacillus subtilis produced equally effective DPP-IV inhibitory activity in hydrolysates of tuna cooking juice (Huang, Jao, Ho \& Hsu, 2012). 
A survey of the literature thus shows that various proteolytic enzyme preparations and process conditions have been reported for production of gelatin hydrolysates or purified fractions with either ACE or DPP-IV inhibitory activity. However, with the exception of a recent study by Guo et al. (2015) reporting the occurrence of both of these bioactivities following simulated gastrointestinal digestion of Alaska pollock skin collagen by pepsin and Corolase PP, to our knowledge no study has investigated the conditions for enzymatically producing gelatin hydrolysates with concurrent ACE and DPP-IV inhibitory activities. Therefore, the objective of this study was to use the gelatin extracted from steelhead fish skin as a substrate to investigate the potential of commercially available enzyme preparations, applied either individually or in succession, to produce gelatin hydrolysates possessing both DPP-IV and ACE inhibitory activities.

\section{Materials and Methods}

\subsection{Materials}

Steelhead (Oncorhynchus mykiss) skin was supplied fresh on ice by Albion Fisheries (Richmond, BC, Canada) and was kept at $-25^{\circ} \mathrm{C}$ until used.

Alcalase ${ }^{\circledR} 2.4 \mathrm{~L}$ (from Bacillus licheniformis, $\geq 2.4 \mathrm{AU} / \mathrm{g}$ ), manufactured by Novozyme Inc., was supplied by Brenntag Canada Inc. (Langley, BC, Canada). Bromelain was from Ultra Bio-Logics Inc. (Châteauguay, QC, Canada) while Corolase ${ }^{\circledR} \mathrm{N}$ was donated by AB Enzymes GmbH (Darmstadt, Germany). Protease P "Amano" 6SD and Protease M “Amano" SD were kindly donated by Amano Enzymes USA Co., Ltd. (Elgin, IL, USA) while pepsin (P-7012), papain (P-3375), dipeptidyl 
peptidase IV (D-7052), and angiotensin-I converting enzyme (A-6778) were products from Sigma-Aldrich (St. Louis, MO, USA). Trinitrobenzenesulfonic acid (TNBSA) was purchased from Fisher Scientific (Ottawa, ON, Canada) while Gly-Pro- $p$-nitroanilide hydrochloride and hippuryl-His-Leu-OH were products of Bachem (Torrance, CA, USA).

\subsection{Gelatin extraction from steelhead skin}

Steelhead skin was thawed at $4^{\circ} \mathrm{C}$ overnight. The residual flesh attached to the skin was manually removed by scraping and the skin was cut into smaller pieces before carrying out the extraction protocol as outlined in Li-Chan et al. (2012). The swollen skin was extracted with 1:2(w/v) skin-to-water at $70^{\circ} \mathrm{C}$ for $2 \mathrm{~h}$, after which the extract was coarsely filtered through cheese cloth followed by oil sieve before freeze-drying.

\subsection{Production of gelatin hydrolysates}

The protease enzyme preparations used in this study are shown in Table 1. Steelhead gelatin hydrolysates were prepared by adding the proteases for the designated amount of time to $2 \%(\mathrm{w} / \mathrm{v})$ gelatin solution at the optimal $\mathrm{pH}$ and temperature for the particular protease. To terminate the hydrolysis, a $100 \mu \mathrm{l}$ aliquot of the hydrolysate was first removed and treated with $100 \mu \mathrm{l}$ of $24 \%$ trichloroacetic acid for the analysis of extent of hydrolysis, then the remaining hydrolysate was immediately boiled for 10 min and stored at $-18^{\circ} \mathrm{C}$ until used for the bioactivity assays.

Preliminary experiments were conducted with several enzyme preparations used individually (Protease P “Amano"6SD, Protease M “Amano"SD, pepsin, Alcalase and CorolaseN) or two enzymes sequentially (pepsin and CorolaseN). Based on those preliminary results, subsequent experiments were conducted involving a first stage 
hydrolysis using Alcalase, bromelain, papain, Protease P “Amano"6SD or Protease M "Amano"SD, followed by a second hydrolysis using either CorolaseN or pepsin.

Hydrolysates were coded as follows: the first capital letter code represents the protease used in the hydrolysis (A: Protease P "Amano" 6SD, B: bromelain, $\mathbf{C}$ :

CorolaseN, L: Alcalase, M: Protease M “Amano” SD, P: pepsin, Pa: papain), and the subscript number following it stands for the percent protease applied while the number after states the duration of hydrolysis in hours. When two enzymes were used in the hydrolysis, then a second capital letter was introduced representing the second protease, followed by the subscript number indicating the percent enzyme and a number showing the time of hydrolysis. For example, the hydrolysate code $\mathrm{Pa}_{4} 2 \mathrm{P}_{1} 2$ stands for first hydrolysis with $4 \%$ papain for $2 \mathrm{~h}$ followed by $1 \%$ pepsin hydrolysis for another $2 \mathrm{~h}$.

\subsection{Extent of hydrolysis}

The $\alpha$-amino content of the hydrolysates was determined in triplicate by reaction with TNBSA following the method described by Liceaga-Gesualdo \& Li-Chan (1999). A standard curve was constructed using $0.2-2.5 \mathrm{mM}$ leucine, and the $\alpha$-amino content of the samples was expressed as milliequivalents of leucine per gram of dried gelatin (meq/g) to represent the extent of hydrolysis (EH).

\subsection{Determination of angiotensin-I converting enzyme inhibitory activity}

The ACE inhibitory activity in percentage was determined following the protocol as outlined in Cheung \& Li-Chan (2010). ACE inhibitory activity was determined in triplicate at a final assay concentration of $0.29 \mathrm{mg} / \mathrm{ml}$. 


\subsection{Determination of dipeptidyl-peptidase IV inhibitory activity}

The DPP-IV inhibitory activity in percentage was determined using the method of Lacroix \& Li-Chan (2013). The DPP-IV inhibitory activity was determined in triplicate at a final assay concentration of $0.5 \mathrm{mg} / \mathrm{ml}$.

\subsection{Ultrafiltration}

Hydrolysates were fractionated by ultrafiltration using Amicon ultra-4 centrifugal filter units with molecular weight cutoff membranes of $3 \mathrm{kDa}$ (EMD Millipore; Billerica, MA, USA). The samples were centrifuged using the $3 \mathrm{kDa}$ unit at $3600 \mathrm{rpm}$ at $4^{\circ} \mathrm{C}$ for 30 min to yield the retentate $(>3 \mathrm{kDa})$ and permeate $(<3 \mathrm{kDa})$. The $<3 \mathrm{kDa}$ fractions were freeze-dried to determine their ACE and DPP-IV inhibitory activities.

\subsection{Statistical analysis}

One-way analysis of variance (ANOVA) was used to determine significant difference in EH between enzyme treatments. Two-way ANOVA was used to determine significant difference in ACE and DPP-IV inhibition of hydrolysates (1) between first enzyme treatment and after sequential hydrolysis, and (2) between unfractionated and $<3$ $\mathrm{kDa}$ fractions. Treatments that were significantly different were further analyzed for differences between samples using Tukey's test. All analyses were performed using Minitab 15.0 statistical program and significant differences were established at $\mathrm{p}<0.05$. 


\section{Results}

\subsection{Preliminary experiments to screen enzymes for producing gelatin hydrolysates with}

\section{$A C E$ and DPP-IV inhibitory activities}

The extent of hydrolysis (EH) achieved after $6 \mathrm{~h}$ incubation with the enzymes selected in the preliminary experiments varied significantly depending on the enzyme used for hydrolysis, with the hydrolysates prepared using pepsin and CorolaseN showing the lowest EH (0.3 and 0.8 meq/g, respectively), whereas that produced using Protease $\mathrm{P}$ “Amano" 6SD reached the highest EH of $2.1 \mathrm{meq} / \mathrm{g}$ (Table 2).

None of these hydrolysates produced showed promising bioactivities; however, ultrafiltration yielded $<3 \mathrm{kDa}$ fractions that exhibited significantly better ACE and DPPIV inhibitory activities than the whole hydrolysates (Table 2). Interestingly, highest inhibitory activity after ultrafiltration was observed for the two hydrolysates with lowest EH. Specifically, the $<3 \mathrm{kDa}$ fractions from hydrolysates prepared using CorolaseN and pepsin showed ACE (67 and 62\%, respectively) and DPP-IV (35 and 44\%, respectively) inhibition that were significantly better than the $<3 \mathrm{kDa}$ fractions from hydrolysates made with Protease P “Amano” 6SD, Protease M “Amano” SD and Alcalase (Table 2).

\subsection{Sequential hydrolysis of gelatins using CorolaseN and pepsin}

Since the $<3 \mathrm{kDa}$ fractions from CorolaseN and pepsin showed the highest ACE and DPP-IV inhibitory activity, sequential hydrolysis using these two enzymes was investigated to produce four hydrolysate samples, two of which were hydrolyzed by each enzyme for $3 \mathrm{~h}\left(\mathrm{P}_{1} 3 \mathrm{C}_{1} 3, \mathrm{C}_{1} 3 \mathrm{P}_{1} 3\right)$, while the other two were prepared by hydrolysis with each enzyme for $6 \mathrm{~h}\left(\mathrm{P}_{1} 6 \mathrm{C}_{1} 6, \mathrm{C}_{1} 6 \mathrm{P}_{1} 6\right)$. The $\mathrm{EH}$ was monitored over the hydrolysis 
duration, and showed that CorolaseN was more effective in hydrolyzing gelatins in comparison to pepsin, yet all four hydrolysates reached very similar EH towards the end of the hydrolysis (Table 3).

The ACE and DPP-IV inhibition were assayed at $\mathrm{t}=0 \mathrm{~h}$ as well as at the end of each of the two stages of hydrolysis, to determine the effect of each enzyme on the inhibitory activities (Table 3). Hydrolysates produced with pepsin as the first enzyme (i.e. $\left.\mathrm{P}_{1} 3 \mathrm{C}_{1} 3, \mathrm{P}_{1} 6 \mathrm{C}_{1} 6\right)$ did not show improvement in bioactivities after the first stage compared to the starting material at $\mathrm{t}=0 \mathrm{~h}$, but further hydrolysis for either 3 or $6 \mathrm{~h}$ with CorolaseN significantly improved both ACE and DPP-IV inhibitory activities (Table 3). Initial hydrolysis with CorolaseN for either 3 or $6 \mathrm{~h}$ showed better ACE inhibitory activities in comparison to the starting material. However, no further improvements in ACE inhibition were observed after successive hydrolysis of CorolaseN hydrolysates with pepsin $\left(\mathrm{C}_{1} 3 \mathrm{P}_{1} 3, \mathrm{C}_{1} 6 \mathrm{P}_{1} 6\right)$ (Table 3). In contrast, significant increase in the DPP-IV inhibitory activity was observed when the $6 \mathrm{~h}$ CorolaseN-hydrolyzed sample underwent further hydrolysis with pepsin for $6 \mathrm{~h}$. This hydrolysate $\left(\mathrm{C}_{1} 6 \mathrm{P}_{1} 6\right)$ also displayed the highest (29\%) ACE inhibitory activity, compared to the other three hydrolysates produced by successive hydrolysis with pepsin and CorolaseN (Table 3).

\subsection{Investigation of two-enzyme hydrolysis of gelatins using CorolaseN or pepsin as}

\section{the second enzyme}

Protease P “Amano" 6SD (A), Protease M “Amano" SD (M), bromelain (B), Alcalase (L), and papain $(\mathbf{P a})$, which were either shown in the preliminary study (section 3.1) or previously reported in the literature (section 1) to effectively hydrolyze gelatins to 
produce bioactive hydrolysates, were employed as the first enzyme in sequential hydrolysis experiments, with CorolaseN $(\mathbf{C})$ or pepsin $(\mathbf{P})$ as the second enzyme. Three sets of steelhead gelatin hydrolysates were prepared under four different conditions for the first stage of hydrolysis (specifically, $1 \%$ or $4 \%$ enzyme and $2 \mathrm{~h}$ or $6 \mathrm{~h}$ hydrolysis time); two sets of these hydrolysates were then subjected to a second hydrolysis using either $1 \%$ CorolaseN or $1 \%$ pepsin for another $2 \mathrm{~h}$.

\subsubsection{Extent of hydrolysis}

The EH for all the samples is displayed in Figure 1. Among all the enzymes investigated, hydrolysates prepared using Protease P "Amano" 6SD individually (A) or with two enzymes successively $(A+P$ and $A+C)$ showed the highest $\mathrm{EH}(2-4$ meq Leu/g) for all conditions tested (Figure 1a), while hydrolysates prepared using bromelain (namely B, B+P, B+C) had the lowest (1 - 1.5 meq Leu/g) (Figure 1c).

Increasing the enzyme concentration from 1 to $4 \%$ and hydrolysis time from 2 to $6 \mathrm{~h}$ had greatest effect on EH of hydrolysates prepared by Protease P "Amano" 6SD and Protease M “Amano” SD (Figures 1a and 1b). Higher EH was also obtained for hydrolysates prepared by using $4 \%$ than $1 \%$ papain, but increasing the duration of hydrolysis did not affect EH in this case (Figure 1e). Only moderate effects of enzyme concentration and hydrolysis time were observed in this study for hydrolysates prepared with bromelain and Alcalase (Figures 1c and 1d). The effects of successive enzyme hydrolysis with pepsin or CorolaseN on EH were varied, depending not only on the specific enzyme used for the first stage of hydrolysis, but also on the enzyme concentration and hydrolysis time. 


\subsubsection{ACE inhibitory activity}

ACE inhibitory activities of all samples are shown in Figure 2, with the highest activities being shown for the sample produced by 6 h hydrolysis with $4 \%$ Protease $\mathrm{P}$ “Amano" 6SD, as well as several hydrolysates produced with CorolaseN as a second enzyme (Figure 2). Despite only moderate increases in $\mathrm{EH}$ being noted for some samples as a function of higher enzyme concentration and/or hydrolysis duration (Figure 1), the ACE inhibitory activity was shown to be affected by these different conditions (Figure 2), suggesting that the additional hydrolysis achieved with higher enzyme concentration and longer duration was effectively generating shorter peptides with ACE inhibitory activity.

Most of the hydrolysates obtained after successive hydrolysis with CorolaseN showed good ACE inhibitory activity, with significant improvements in ACE inhibition being particularly notable for the hydrolysates produced initially using bromelain $(\mathrm{B}+\mathrm{C}$, Figure 2c) and papain ( $\mathrm{Pa}+\mathrm{C}$, Figure 2e). Interestingly, as illustrated by $\mathrm{L}_{4} 2 \mathrm{C}_{1} 2$, which is the hydrolysate produced by $4 \%$ Alcalase for $2 \mathrm{~h}$ followed by subsequent CorolaseN hydrolysis, an increase in the ACE inhibitory activity (Figure 2d) could be observed even with limited effects on EH by CorolaseN (Figure 1d).

The hydrolysate produced using only 4\% Protease P "Amano" 6SD for $6 \mathrm{~h}$ (Figure 2a) showed high ACE-inhibitory activity. On the contrary, all samples hydrolyzed first with Protease $\mathrm{P}$ “Amano" 6SD followed by pepsin hydrolysis (A+P, Figure 2a) suffered significant reductions in ACE inhibitory activity. In fact, successive hydrolysis with pepsin generally resulted in either significant decreases or no change in ACE inhibition for most of the hydrolysates in this study, with the exception of the 
hydrolysate produced using $1 \%$ bromelain for $2 \mathrm{~h}\left(\mathrm{~B}_{1} 2 \mathrm{P}_{1} 2\right)$, which showed a significant increase by the action of pepsin (Figure 2c).

\subsubsection{DPP-IV inhibitory activity}

Most of the hydrolysates produced after hydrolysis with the first enzyme had DPP-IV inhibitory activity at or below $20-30 \%$, and the activities did not vary much among protease and hydrolysis conditions tested (Figure 3). Hydrolysates prepared using 4\% papain were the exception, showing significantly higher DPP-IV inhibition (40 $45 \%$ ), which was also higher in comparison to hydrolysates produced using $1 \%$ papain (Figure 3e).

When pepsin was used to further hydrolyze the samples, several hydrolysates showed significant albeit moderate increases in DPP-IV inhibition. Successive hydrolysis using CorolaseN also resulted in increased DPP-IV inhibitory activity in some hydrolysates, but again the effect was not strong. Interestingly, the $6 \mathrm{~h}$ hydrolysate

produced with $4 \%$ papain, which itself displayed potent DPP-IV inhibition, showed a slight but significant drop in inhibitory activity after further hydrolysis with either pepsin or CorolaseN (Figure 3e).

\subsection{ACE and DPP-IV inhibitory activities of $<3 \mathrm{kDa}$ fractions}

The samples produced by $2 \mathrm{~h}$ hydrolysis using $4 \%$ enzyme concentration $\left(\mathrm{A}_{4} 2\right.$, $\mathrm{M}_{4} 2, \mathrm{~B}_{4} 2, \mathrm{~L}_{4} 2$ and $\left.\mathrm{Pa}_{4} 2\right)$, together with $\mathrm{C}_{1} 6 \mathrm{P}_{1} 6$, were further examined after ultrafiltration to obtain the $<3 \mathrm{kDa}$ fractions. Prior to ultrafiltration, these hydrolysate samples exhibited 
moderate ACE inhibitory activities $(19-29 \%)$ and moderate to good DPP-IV inhibitory activities $(19-45 \%)$ (Table 4).

ACE inhibitory activity increased $\sim 2$-fold in the $<3 \mathrm{kDa}$ fractions of all samples with the exception of $\mathrm{L}_{4} 2$, whose inhibitory activity remained unchanged (Table 4). On the other hand, the effect of ultrafiltration on DPP-IV inhibitory activity was moderate, with the greatest change being observed in $\mathrm{C}_{1} 6 \mathrm{P}_{1} 6$, which increased from $35 \%$ to $44 \%$ inhibition (Table 4). Among all the samples investigated, the ultrafiltrates from $\mathrm{Pa}_{4} 2$ and $\mathrm{C}_{1} 6 \mathrm{P}_{1} 6$ showed the strongest inhibition of both ACE and DPP-IV. The $<3 \mathrm{kDa}$ fraction of $\mathrm{Pa}_{4} 2$ showed 54\% ACE inhibition and 42\% DPP-IV inhibition while that of $\mathrm{C}_{1} 6 \mathrm{P}_{1} 6$ showed 63\% ACE inhibition and 44\% DPP-IV inhibition (Table 4). The recovery of solids of these $<3 \mathrm{kDa}$ fractions also varied, with that of $\mathrm{Pa}_{4} 2$ reaching $54 \%$ while that of $\mathrm{C}_{1} 6 \mathrm{P}_{1} 6$ was $32 \%$ (Table 4$)$.

\section{Discussion}

Although several studies in the literature have reported on the use of commercial enzyme preparations for production of fish skin gelatin hydrolysates with either ACE inhibitory activity or DPP-IV inhibitory activity, to date no study has investigated the production of gelatin hydrolysates exhibiting both ACE and DPP-IV inhibitory activities. Products with this dual bioactivity could be of significant commercial interest given the fact that hypertension and diabetes frequently co-exist in patients. Therefore, in the present study, we first screened the ability of different enzyme preparations when used individually to produce hydrolysates from steelhead gelatin with the dual bioactivities, 
and then investigated the effect of successive hydrolysis with a second enzyme on the properties of the resulting hydrolysates.

The amino acid composition of gelatins prepared from various fish skins show some species-to-species variability, but overall are similar in terms of the relative abundance of amino acids being in the following order: Gly >> Ala, Pro + Hyp > Glx $($ Glu + Gln), Ser, Arg, Asx (Asp + Asn) > other amino acids (Wang et al., 2015). Owing to the unique structure of fish skin gelatin, particularly the high contents of Gly, Ala, Hyp and Pro, it is perhaps not surprising that some of the proteases used in this study were not able to hydrolyze the gelatin well when used on their own under the conditions used in this study; in particular, hydrolysates produced using $1 \%$ pepsin or $1 \%$ CorolaseN for $6 \mathrm{~h}$ had EH values of only 0.3 and 0.8 meq Leu/g, respectively (Table 2).

On the other hand, when used at $1 \%$ concentration, five other enzyme preparations investigated in this study, namely Alcalase, bromelain, papain, Protease $\mathrm{P}$ “Amano" 6SD and Protease M “Amano" SD, all produced hydrolysates with EH values greater than $1.0 \mathrm{meq} / \mathrm{g}$ (Table 2 and Figure 1), with the latter two enzymes in particular being the most effective at hydrolyzing gelatin (Figure 1). The manufacturers' specifications for these two fungal (Aspergillus) enzyme preparations indicate their high proteolytic activity, "applicable to various natural seasonings and low molecular weight peptides" (Amano Enzyme Inc., 2007). In fact, collagen and particularly elastin have been reported as readily hydrolyzed substrates by oryzin (Barrett, Rawlings \& Woessner, 1998), which represents the same enzyme (EC 3.4.21.63) as Protease P "Amano" 6SD. With respect to the other three enzyme preparations, hydrolysates produced by papain showed higher EH than those made by Alcalase and bromelain, particularly when 
the enzymes were used at $4 \%$ concentration (Figure 1). Bromelain is a cysteine endoproteinase that shows preference for substrates bearing polar amino acid residues in both the P1 and P1' positions (Barrett et al., 1998), and cleavage of substrates with Pro residues at P3 and P4 have also been noted (MEROPS, 2016; Rawlings, Barrett \& Finn, 2016). In comparison, both papain and Alcalase are considered to have fairly broad specificity (Barrett et al., 1998). Papain has some preference for bulky non polar side chains and basic side chains at P2 and P1 positions, respectively, and for Gln residues at P1' as well as P2' positions, while Alcalase shows preference for Ala and Ser residues at P1, although Gly, Pro, Ala, Val and Ser were all frequently found at various P4-P4' subsites of substrates investigated (MEROPS, 2016). It is interesting to note that the results of the present study showed some different trends than those reported by Choonpicharn et al. (2015), where Nile tilapia skin gelatin hydrolysates prepared using papain showed the highest $\mathrm{EH}$, followed by that of bromelain and the lowest by Alcalase, or by Sae-leaw, O-Callaghan, Benjakul \& O-Brien (2016), who noted extensive hydrolysis by the action of Alcalase on skin gelatin from Alaska pollack, sole, giant squid and seabass. This variation in results could be attributed to the inherent difference in the gelatin structures from different fish species as well as to different $\mathrm{pH}$ and temperature conditions used for the hydrolysis.

Since both ACE and DPP-IV inhibitory activities have frequently been reported to be associated with lower molecular weight peptides (Iwaniak et al., 2014; Power et al., 2014), ultrafiltration using $3 \mathrm{kDa}$ molecular weight cutoff membranes was conducted to obtain $<3 \mathrm{kDa}$ fractions from the gelatin hydrolysates. The results showed that the $<3$ $\mathrm{kDa}$ fractions of hydrolysates contained significantly better ACE and DPP-IV inhibitory 
activities than the whole, unfractionated hydrolysates (Tables 2 and 4), in agreement with the reports that smaller peptides are associated with these bioactivities. Thus, ultrafiltration was shown in this study to serve as a useful process for obtaining gelatin hydrolysate fractions enriched in the lower molecular weight peptides and exhibiting higher bioactivity. However, when considering the potential for further development of these fractions as functional food ingredients or nutraceuticals, the practical issue of product yield must be taken into account. The recovery of solids in the $<3 \mathrm{kDa}$ ultrafiltration fractions in this study ranged from $3 \%$ to $54 \%$ of the original starting gelatin weight, with the lowest and highest yields obtained for the fractions from pepsin $\left(\mathrm{P}_{1} 6\right)$ and papain $\left(\mathrm{Pa}_{4} 2\right)$, respectively (Tables 2 and 4$)$.

As an alternative to ultrafiltration, we also investigated successive hydrolysis to generate hydrolysates with higher EH as well as bioactivities without incurring losses of solid matter associated with the ultrafiltration process. The preliminary screening had shown that the $<3 \mathrm{kDa}$ fractions of CorolaseN and pepsin contained higher ACE and DPP-IV inhibitory activities than the fractions produced by the other enzymes (Table 2), but this potential was limited by the low extent of hydrolysis achieved by these two proteases even when used successively (Table 3). Therefore, additional experiments were conducted to perform the first stage hydrolysis using enzymes that had shown good capacity for hydrolyzing gelatin, namely Protease P "Amano" 6SD, Protease M "Amano" $\mathrm{SD}$, bromelain, Alcalase and papain. Then, these hydrolysates were further incubated with either pepsin or CorolaseN, the enzymes that had been shown in the preliminary screening to yield low molecular weight peptide fractions with high bioactivity. 
CorolaseN has been recommended by the manufacturer to be used either as a single enzyme or in combination with other proteinases (AB Enzymes, 2009). The zinc metalloendoprotease bacillolysin, which refers to the same enzyme (EC 3.4.24.28) as CorolaseN, prefers substrates with hydrophobic residues such as Ala at the P1' and P2' positions (Barrett et al., 1998; MEROPS, 2016), while Gly residues dominate at the P1 position and are also often found at both $\mathrm{P} 2$ and P3 positions (MEROPS, 2016); these are residues that are abundant in gelatin. On the other hand, pepsin (EC 3.4.23.1) preferentially cleaves at Phe, Met, Trp and Leu in position P1, while the presence of Pro in position P4 and P3 will incur a favourable effect (Power, Harley \& Myers, 1977).

Hydrolysis using pepsin or CorolaseN as a second step had some impact on EH of the final hydrolysates. However, the effects of the second hydrolysis on ACE and DPPIV inhibitory activity indicated that EH does not directly correlate to bioactivity. Some hydrolysates prepared first using P "Amano" 6SD followed by pepsin, as well as those prepared first with bromelain then CorolaseN, showed significant increases in EH (Figure 1). These hydrolysates produced from successive $\mathrm{P}$ "Amano" $6 \mathrm{SD}$ then pepsin $(\mathrm{A}+\mathrm{P})$ suffered a significant reduction in ACE inhibitory activities while some showed increase in DPP-IV inhibition (Figures 2a and 3a). On the contrary, those prepared using successive bromelain then CorolaseN $(\mathrm{B}+\mathrm{C})$ yielded hydrolysates with higher $\mathrm{ACE}$ inhibitory activities yet only $\mathrm{B}_{1} 2$ showed improvement in DPP-IV inhibitory activity after CorolaseN hydrolysis (Figures 2c and 3c).

Few hydrolysates, namely $\mathrm{A}_{4} 6, \mathrm{M}_{4} 6 \mathrm{C}_{1} 2, \mathrm{~B}_{4} 2 \mathrm{C}_{1} 2, \mathrm{~Pa}_{4} 2 \mathrm{C}_{1} 2$ and $\mathrm{Pa}_{4} 6 \mathrm{C}_{1} 2$, showed ACE inhibitory activity over $40 \%$ in the whole hydrolysate (Figure 2); among these, $\mathrm{Pa}_{4} 2 \mathrm{C}_{1} 2$ and $\mathrm{Pa}_{4} 6 \mathrm{C}_{1} 2$ also displayed DPP-IV inhibitory activity over $40 \%$ (Figure 3). In 
fact, some general trend could be observed on the effect on bioactivities after successive hydrolysis with pepsin and CorolaseN. Successive hydrolysis with pepsin either diminished or had no effect on ACE inhibition (Figure 2). The exception to this was $\mathrm{B}_{1} 2 \mathrm{P}_{1} 2$, the hydrolysate produced by $1 \%$ bromelain for $2 \mathrm{~h}$ followed by $1 \%$ pepsin for another $2 \mathrm{~h}$, which showed a significant increase in ACE-inhibitory activity, albeit the inhibition was still below 20\% (Figure 2c).

On the other hand, DPP-IV inhibitory activity of most hydrolysates was either not affected or else showed moderate increases after successive hydrolysis with pepsin (Figure 3). Again an exception to this trend was observed, in this case a decrease in DPPIV inhibitory activity being observed for $\mathrm{Pa}_{4} 6 \mathrm{P}_{1} 2$, the hydrolysate produced by $4 \%$ papain for $6 \mathrm{~h}$ followed by successive hydrolysis with pepsin (Figure 3e). The two cases where successive hydrolysis markedly increased DPP-IV inhibitory activity were $\mathrm{C}_{1} 6 \mathrm{P}_{1} 6$ and $\mathrm{Pa}_{1} 6 \mathrm{P}_{1} 2$, in which further pepsin hydrolysis boosted DPP-IV inhibitory activity of CorolaseN hydrolysate from 22 to $37 \%$ (Table 2), and papain hydrolysate from 30 to $40 \%$ (Figure 3e).

Thus even though pepsin, when used alone, produced gelatin hydrolysates with good ACE and DPP-IV inhibitory activities in the low molecular weight fraction after ultrafiltration (Table 2), the results of two-enzyme hydrolysis indicate that pepsin cleaves at sites on peptides generated by the action of the first enzyme to result in lower ACE inhibitory activity of the final hydrolysates (Figure 2). These observations could partly be explained by the fact that pepsin has been reported to cleave the $\beta$ chain of insulin at the peptide bonds Phe-Val, Gln-His, Glu-Ala, Ala-Leu, Leu-Tyr, Tyr-Leu, Gly-Phe, Phe-Phe, Phe-Tyr (White \& White, 1997), some of which have been reported in the sequences of 
ACE inhibitory peptides (BIOPEP, 2016; Minkiewicz, Dziuba, Iwaniak, Dziuba \& Darewicz, 2008).

On the contrary, CorolaseN used as the enzyme for the second stage of hydrolysis either significantly improved the ACE inhibitory activity or else had no effect (Figure 2); the only exception was $\mathrm{A}_{1} 6 \mathrm{C}_{1} 2$, the hydrolysate prepared using $1 \% \mathrm{P}$ "Amano" $6 \mathrm{SD}$ for 6 $\mathrm{h}$ followed by $1 \%$ CorolaseN for $2 \mathrm{~h}$, which showed a significant decrease (Figure 2a). In general, successive hydrolysis with CorolaseN did not have much effect on DPP-IV inhibitory activity. Moderate increases in activity were observed for $\mathrm{B}_{1} 2 \mathrm{C}_{1} 2, \mathrm{~L}_{1} 6 \mathrm{C}_{1} 2$, $\mathrm{L}_{4} 6 \mathrm{C}_{1} 2$ and $\mathrm{Pa}_{1} 6 \mathrm{C}_{1} 2$, and a decrease in activity was noted in $\mathrm{Pa}_{4} 6 \mathrm{C}_{1} 2$, which nevertheless remained one of the hydrolysates that displayed highest DPP-IV inhibitory activity. (Figure 3).

Among all the samples investigated, $\mathrm{Pa}_{4} 2 \mathrm{C}_{1} 2$ and $\mathrm{Pa}_{4} 6 \mathrm{C}_{1} 2$ were the best candidates for preparing hydrolysates with bioactivities, if no further processing such as ultrafiltration was to be considered. These samples showed ACE inhibition of 42 and $45 \%$, respectively, and DPP-IV inhibition of 42 and 41\%, respectively (Figure 3e). When ultrafiltration was implemented, then the $<3 \mathrm{kDa}$ fractions of $\mathrm{Pa}_{4} 2$ showed $54 \%$ ACE inhibition and $42 \%$ DPP-IV inhibition while that of $\mathrm{C}_{1} 6 \mathrm{P}_{1} 6$ showed $63 \%$ ACE inhibition and 44\% DPP-IV inhibition (Table 4). The recovery of solids was 54 and $32 \%$ in the <3 $\mathrm{kDa}$ fractions of $\mathrm{Pa}_{4} 2$ and $\mathrm{C}_{1} 6 \mathrm{P}_{1} 6$, respectively (Table 4), compared to $100 \%$ for the whole (i.e. not ultrafiltered) hydrolysates $\mathrm{Pa}_{4} 2 \mathrm{C}_{1} 2$ and $\mathrm{Pa}_{4} 6 \mathrm{C}_{1} 2$.

The level of ACE inhibition (42-63\% at $0.286 \mathrm{mg} / \mathrm{ml}$ final assay concentration) found in the present study was comparable or better than those reported for gelatin hydrolysates in the literature. Kittiphattanabawon, Benjakul, Visessanguan \& Shahidi 
(2013) reported $\mathrm{IC}_{50}$ ranging from 0.9 to $1.8 \mathrm{mg} / \mathrm{ml}$ for blacktip shark skin gelatin hydrolysates prepared using papaya latex enzyme while Ngo et al. (2014) indicated 30 $70 \%$ ACE inhibition at $2 \mathrm{mg} / \mathrm{ml}$ for skate skin gelatin hydrolysates prepared by various proteases. In a study on thornback ray skin's gelatin, Lassoued et al. (2015) reported $\mathrm{IC}_{50}$ of 0.95 and $2.07 \mathrm{mg} / \mathrm{ml}$ in the whole hydrolysates prepared using B. subtilis A26 protease and Neutrase, respectively, and 1.98 and $1.75 \mathrm{mg} / \mathrm{ml}$ in the respective size-exclusion chromatography fractions. Furthermore, the DPP-IV inhibitory activity ( $41-44 \%$ at 0.5 $\mathrm{mg} / \mathrm{ml}$ ) of hydrolysates in the current study was also better than the inhibitory activities of $5-45 \%$ at $1 \mathrm{mg} / \mathrm{ml}$ reported for a variety of fish skin gelatin hydrolysates (Wang et al., 2015) and the $\mathrm{IC}_{50}$ values of $1.6-5.2 \mathrm{mg} / \mathrm{ml}$ for various kinds of skin collagen hydrolysates (Hatanaka, Kawakami \& Uraji, 2014).

\section{Conclusions}

In this study, it was shown that steelhead gelatin hydrolysates with strong ACE as well as DPP-IV inhibitory activity could be generated by hydrolysis using pepsin, CorolaseN or papain, followed by ultrafiltration to yield low molecular weight $(<3 \mathrm{kDa})$ fractions with the bioactive peptides. Alternatively, successive hydrolysis with two enzymes was also effective to produce gelatin hydrolysates with dual bioactivity. Using pepsin as a second stage hydrolysis tended to decrease ACE inhibitory activity while slightly increasing DPP-IV inhibitory activity of the hydrolysates, while using CorolaseN as the second enzyme achieved an increase in ACE inhibition with little impact on DPPIV inhibitory activity. These results suggest that it may be possible to further explore the use of CorolaseN as a second step for hydrolysates that have previously been shown to 
exhibit strong DPP-IV inhibitory activity, with the intent to produce more potent ACE inhibition while maintaining the strong DPP-IV inhibition. Among all the hydrolysates produced in this study, the most promising could be $\mathrm{Pa}_{4} 2$ that was obtained using $4 \%$ papain for $2 \mathrm{~h}$, either followed by a second hydrolysis with $1 \%$ CorolaseN for $2 \mathrm{~h}$ or by ultrafiltration to obtain the $<3 \mathrm{kDa}$ fraction. Both of these final products exhibited good in vitro ACE and DPP-IV inhibitory activities and therefore have potential as multifunctional food ingredients or nutraceuticals for the management of hypertension and diabetes. It is recommended that these hydrolysates be further tested for their bioavailability and efficacy in vivo.

\section{Acknowledgments}

The funding for this research was provided by the Natural Sciences and Engineering Research Council of Canada (NSERC - Council Grant No. 121822-11). We thank Albion Fisheries for providing the steelhead skin used in this research, as well as Amano Enzyme Inc. and $\mathrm{AB}$ Enzymes $\mathrm{GmbH}$ for the donations of proteases used in this study. 


\section{References}

AB Enzymes. (2009). Corolase ${ }^{\circledR}$ N description and specification. 2009-12-17 Rev. No. 05. Darmstadt: AB Enzymes GmbH.

Amano Enzyme Inc. (2007). Protein processing. https://www.amanoenzyme.co.jp/eng/productuse/protein.html, accessed May 25, 2016.

Babij, K., Dąbrowska, A., Szołtysik, M., Pokora, M., Zambrowicz, A., \& Chrzanowska, J. (2014). The evaluation of dipeptidyl peptidase (DPP)-IV, $\alpha$-glucosidase and angiotensin converting enzyme (ACE) inhibitory activities of whey proteins hydrolyzed with serine protease isolated from Asian pumpkin (Cucurbita ficifolia). International Journal of Peptide Research and Therapeutics, 20, 483491.

Barrett, A. J., Rawlings, N.D., \& Woessner, J.F. (1998) Handbook of Proteolytic Enzymes. London: Academic Press.

BIOPEP. (2016). The BIOPEP database. http://www.uwm.edu.pl/biochemia/index.php/en/biopep, accessed July 28, 2016.

Boran, G., \& Regenstein, J.M. (2010). Fish gelatins. Advances in Food and Nutrition Research, 60, 119-143.

Byun, H.G., \& Kim, S.-K. (2001). Purification and characterization of angiotensin I converting enzyme (ACE) inhibitory peptides from Alaska pollack (Theragra chalcogramma) skin. Process Biochemistry, 36, 1155-1162.

Campbell, N.R.C., Gilbert, R.E., Leiter, L.A., Larochelle, P., Tobe, S., Chockalingam, A., Ward, R., Morris, D., Tsuyuki, R.T., \& Harris, S.B. (2011). Hypertension in people with type 2 diabetes. Update on pharmacologic management. Canadian Family Physician, 57, 997-1002.

Cheung, I.W.Y., \& Li-Chan, E.C.Y. (2010). Angiotensin-I-converting enzyme inhibitory activity and bitterness of enzymatically-produced hydrolysates of shrimp 
(Pandalopsis dispar) processing byproducts investigated by Taguchi design. Food Chemistry, 122, 1003-1012.

Choonpicharn, S., Jaturasitha S., Rakariyatham, N., Suree, N., \& Niamsup, H. (2015). Antioxidant and antihypertensive activity of gelatin hydrolysate from Nile tilapia skin. Journal of Food Science and Technology, 52(5), 3134-3139.

Estrada-Salas, P.A., Montero-Morán, G.M., Martínez-Cuevas, P.P., González, C., \& Barba de la Rosa, A.P. (2014). Characterization of antidiabetic and antihypertensive properties of canary seed (Phalaris canariensis L.) peptides. Journal of Agricultural and Food Chemistry, 62, 427-433.

Grossman, E., \& Messerli, F.H. (2008). Hypertension and diabetes. In E.Z. Fisman, \& A. Tenenbaum (Eds.), Cardiovascular diabetology: Clinical, metabolic and inflammatory facets (Advances in Cardiology vol. 45 pp. 82-106). Basel: Karger.

Guo, L., Harnedy, P.A., Zhang, L., Li, B., Zhang, Z., Hou, H., Zhao, X., \& FitzGerald, R.J. (2015). In vitro assessment of the multifunctional bioactive potential of Alaska pollock skin collagen following simulated gastrointestinal digestion. Journal of the Science of Food and Agriculture, 95, 1514-1520.

Hatanaka, T., Kawakami, K., \& Uraji, M. (2014). Inhibitory effect of collagen-derived tripeptides on dipeptidylpeptidase-IV activity. Journal of Enzyme Inhibition and Medicinal Chemistry, 29(6), 823-828.

Huang, S.L., Jao, C.L., Ho, K.P., \& Hsu, K.C. (2012). Dipeptidyl-peptidase IV inhibitory activity of peptides derived from tuna cooking juice hydrolysates. Peptides, 35(1), 114-121.

Iwaniak, A., Minkiewicz, P., \& Darewicz, M. (2014). Food-originating ACE inhibitors, including antihypertensive peptides, as preventive food components in blood pressure reduction. Comprehensive Reviews in Food Science and Food Safety, 13, 114-134. 
Khiari, Z., Rico, D., Martin-Diana, A.B., \& Barry-Ryan, C. (2014). Structure elucidation of ACE-inhibitory and antithrombotic peptides isolated from mackerel skin gelatin hydrolysates. Journal of Science and Food Agriculture, 94, 1663-1671.

Kittiphattanabawon, P., Benjakul, S., Visessanguan, W., \& Shahidi, F. (2013). Inhibition of angiotensin converting enzyme, human LDL cholesterol and DNA oxidation by hydrolysates from blacktip shark gelatin. LWT - Food Science and Technology, $51,177-182$.

Lacroix, I.M.E., \& Li-Chan, E.C.Y. (2013) Inhibition of dipeptidyl peptidase (DPP)-IV and $\alpha$-glucosidase activities by pepsin-treated whey proteins. Journal of Agricultural and Food Chemistry, 61, 7500-7506.

Lacroix, I.M.E., \& Li-Chan, E.C.Y. (2016). Food-derived dipeptidyl-peptidase IV inhibitors as a potential approach for glycemic regulation - Current knowledge and future research considerations. Trends in Food Science \& Technology, 54, 1 16.

Lacroix, I.M.E., Meng, G., Cheung, I.W.Y., \& Li-Chan, E.C.Y. (2016). Do whey proteinderived peptides have dual dipeptidyl-peptidase IV and angiotensin I-converting enzyme inhibitory activities? Journal of Functional Foods, 21, 87-96.

Lago, R.M., Singh, P.P., \& Nesto, R.W. (2007) Diabetes and hypertension. Nature Clinical Practice Endocrinology \& Metabolism, 3(10), 667.

Lassoued, I., Mora, L., Barkia, A., Aristoy, M-C., Nasri, M., \& Toldrá, F. (2015). Bioactive peptides identified in thornback ray skin's gelatin hydrolysates by protease from Bacillus subtilis and Bacillus amyloliquefaciens. Journal of Proteomics, 128, 8-17.

Li-Chan, E.C.Y., Hunag, S-L., Jao, C-L., Ho, K-P., \& Hsu, K-C. (2012) Peptides derived from Atlantic salmon skin gelatin as dipeptidy-peptidase IV inhibitors. Journal of Agricultural and Food Chemistry, 60, 973-978. 
Liceaga-Gesualdo, A.M., \& Li-Chan, E.C.Y. (1999). Functional properties of fish protein hydrolysate from herring (Clupea harengus). Journal of Food Science, 64(6), 1000-1004.

Mahmoodani, F., Ghassem, M., Babji, A.S., Yusop, S.M., \& Khosrokhavar, R. (2014). ACE inhibitory activity of pangasius catfish (Pangasius sutchi) skin and bone gelatin hydrolysate. Journal of Food Science and Technology, 51(9), 1847-1856.

MEROPS. (2016). The peptidase database version 10.0 http://merops.sanger.ac.uk/, accessed July 11, 2016.

Minkiewicz, P., Dziuba, J., Iwaniak, A., Dziuba, M., \& Darewicz, M. (2008). BIOPEP database and other programs for processing bioactive peptide sequences. Journal of AOAC International, 91, 965-980.

Ngo, D-H., Ryu, B., \& Kim, S-K. (2014). Active peptides from skate (Okamejei kenojei) skin gelatin diminish angiotensin-I converting enzyme activity and intracellular free radical-mediated oxidation. Food Chemistry, 143, 246-255.

Pal, G.K., \& Suresh, P.V. (2016) Sustainable valorisation of seafood by-products: Recovery of collagen and development of collagen-based novel functional food ingredients. Innovative Food Science and Emerging Technologies, in press, http://dx.doi.org/10.1016/j.ifset.2016.03.015

Power, J.C., Harley, A.D., \& Myers, D.V. (1977). Subsite specificity of porcine pepsin. In Tang, J. (Ed), Acid Proteases: Structure, Function and Biology. New York: Springer US.

Power, O., Nongonierma, A.B., Jakeman, P., \& FitzGerald, R.J. (2014). Food protein hydrolysates as a source of dipeptidyl peptidase IV inhibitory peptides for the management of type 2 diabetes. Proceedings of the Nutrition Society, 73(1), 3446. 
Rawlings, N.D., Barrett, A. J., \& Finn, R.D. (2016). Twenty years of the MEROPS database of proteolytic enzymes, their substrates and inhibitors. Nucleic Acids Research, 44, D343-D350.

Sae-leaw, T., O-Callaghan, Y.C.O., Benjakul, S., \& O-Brien, N.M. (2016). Antioxidant activities and selected characteristics of gelatin hydrolysates from seabass (Lates calcarifer) skin as affected by production processes. Journal of Food Science and Technology, 53, 197-208.

Sila, A., Martinez-Alvarez, O., Haddar, A., Gómez-Guillén, M.C., Nasri, M., Montero, M.P., \& Bougatef, A. (2015). Recovery, viscoelastic and functional properties of Barbel skin gelatin: Investigation of anti-DPP-IV and anti-prolyl endopeptidase activities of generated gelatin polypeptides. Food Chemistry, 168, 478-486.

Vo, T.-S., Ngo, D.-H., Kim, J.-A., Ryu, B., \& Kim, S.-K. (2011). An antihypertensive peptide from tilapia gelatin diminishes free radical formation in murine microglial cells. Journal of Agricultural and Food Chemistry, 59, 12193-12197.

Wang, T-Y., Hsieh, C-H., Hung, C-C., Jao, C-L., Chen, M-C., \& Hsu, K-C. (2015). Fish skin gelatin hydrolysates as dipeptidyl peptidase IV inhibitors and glucagon-like peptide-1 stimulators improve glycaemic control in diabetic rats: A comparison between warm- and cold-water fish. Journal of Functional Foods, 19, 330-340.

White, J.S., \& White, D.C. (1997). Source book of enzymes. Boca Raton: CRC Press.

World Health Organization. (2015). Cardiovascular diseases fact sheet.

http://www.who.int/mediacentre/factsheets/fs317/en/, accessed May 25, 2016.

World Health Organization. (2016a). Diabetes fact sheet. http://www.who.int/mediacentre/factsheets/fs312/en/, accessed May 25, 2016.

World Health Organization. (2016b). Global report on diabetes. apps.who.int/iris/bitstream/10665/204871/1/9789241565257_eng.pdf?ua=1, accessed May 25, 2016. 
Zambrowicz, A., Pokora, M., Setner, B., Dabrowska, A., Szołtysik, M., Babij, K., Szewczuk, Z., Trziszka, T., Lubec, G., \& Chrzanowska, J. (2015). Multifunctional peptides derived from an egg yolk protein hydrolysate: isolation and characterization. Amino Acids, 47, 369-380. 
Table 1. Enzyme products and the conditions of $\mathrm{pH} \&$ temperature used for preparing steelhead gelatin hydrolysates in this study.

\begin{tabular}{|c|c|c|c|c|c|c|}
\hline Enzyme product & Code & $\mathrm{pH}$, temperature & Source of enzyme & EC number & Activity $^{a}$ & Substrate specificity and preference ${ }^{b}$ \\
\hline Protease P “Amano" 6SD & A & {$\left[\mathrm{pH} 7,40^{\circ} \mathrm{C}\right]$} & Aspergillus melleus & EC 3.4.21.63 & $\geq 60,000 \mathrm{u} / \mathrm{g}$ & - \\
\hline Bromelain & B & {$\left[\mathrm{pH} 7,50^{\circ} \mathrm{C}\right]$} & Pineapple stem & EC 3.4.22.32 & 2000 GDU/g & Polar residues at P1 \& P1'; Pro at P3 \& P4 \\
\hline Corolase ${ }^{\circledR} \mathrm{N}$ & C & {$\left[\mathrm{pH} 7.5,55^{\circ} \mathrm{C}\right]$} & Bacillus subtilis & EC 3.4.24.28 & $\geq 600 \mathrm{UHb} / \mathrm{g}$ & Gly at P1, P2 \& P3; Leu at P1'; Ala at P1' \& P2' \\
\hline Alcalase $^{\circledR} 2.4 \mathrm{~L}$ & L & {$\left[\mathrm{pH} 8,50^{\circ} \mathrm{C}\right]$} & Bacillus licheniformis & EC 3.4.21.62 & $\geq 2.4 \mathrm{AU} / \mathrm{g}$ & Broad specificity; Ala, Ser at P1 \\
\hline Protease M “Amano" SD & M & {$\left[\mathrm{pH} 6,50^{\circ} \mathrm{C}\right]$} & Aspergillus oryzae & EC 3.4.23.18 & $\geq 5,500 \mathrm{u} / \mathrm{g}$ & Broad specificity; hydrophobic residues at P1 \& P1' \\
\hline Pepsin & $\mathrm{P}$ & {$\left[\mathrm{pH} 2,37^{\circ} \mathrm{C}\right]$} & Porcine gastric mucosa & EC 3.4.23.1 & $\begin{array}{l}\geq 2,500 x \\
10^{3} \mathrm{u} / \mathrm{g}\end{array}$ & $\begin{array}{l}\text { Hydrophobic (esp aromatic) residues at P1 \& P1'; Phe, Met, } \\
\text { Trp, Leu at P1; Phe, Leu at P1'; Pro at P3, P4 }\end{array}$ \\
\hline Papain & $\mathrm{Pa}$ & {$\left[\mathrm{pH} 6,65^{\circ} \mathrm{C}\right]$} & Papaya latex & EC 3.4.22.2 & $\begin{array}{l}1500- \\
10,000 \mathrm{u} / \mathrm{g}\end{array}$ & $\begin{array}{l}\text { Fairly broad specificity; Arg and Phe at P1; Leu, Phe at P2; } \\
\text { Gln at } \text { P1' }^{\prime} \text { and } \text { P2'; }^{\prime} \text { Asp at } \text { P4' }^{\prime}\end{array}$ \\
\hline
\end{tabular}

a as specified by the manufacturer/supplier of the enzyme product.

${ }^{b}$ a summary of information from Barrett et al. (1998), MEROPS (2016), Power et al. (1977) and White \& White (1997). 
Table 2. Extent of hydrolysis (EH) of steelhead gelatin hydrolysates prepared using $1 \%$ protease $P$ “Amano" 6SD (A), protease M “Amano" SD (M), Alcalase (L), CorolaseN (C) and pepsin (P), after 6 hr of hydrolysis, and the angiotensin-I converting enzyme (ACE) inhibitory activity and dipeptidyl-peptidase IV (DPP-IV) inhibitory activity of the whole hydrolysates and their $<3 \mathrm{kDa}$ fractions.

\begin{tabular}{|c|c|c|c|c|c|c|}
\hline \multirow[b]{2}{*}{ Sample } & \multirow{2}{*}{$\begin{array}{c}\text { EH } \\
(\mathrm{meq} / \mathrm{g})^{\mathrm{ae}}\end{array}$} & \multirow{2}{*}{$\begin{array}{c}\text { Solid } \\
\text { Recovery in } \\
<3 \mathrm{kDa} \\
\text { fraction }(\%)^{\mathrm{b}}\end{array}$} & \multicolumn{2}{|c|}{ ACE Inhibition (\%) ${ }^{c}$} & \multicolumn{2}{|c|}{ DPP-IV Inhibition (\%) } \\
\hline & & & Whole ${ }^{e}$ & $<3 \mathrm{kDa}^{\mathrm{e}}$ & Whole & $<3 \mathrm{kDa}^{\mathrm{e}}$ \\
\hline$A_{1} 6$ & $2.1 \mathrm{e}$ & 43 & $10 \mathrm{cx}$ & 38 by & $13 \mathrm{ax}$ & 24 ay \\
\hline$M_{1} 6$ & $1.6 \mathrm{~d}$ & 30 & $\mathrm{NI}$ ax & 42 by & 15 ax & 23 ay \\
\hline $\mathrm{L}_{1} 6$ & $1.2 \mathrm{c}$ & 34 & $\mathrm{NI}$ ax & 23 ay & 14 ax & 20 ay \\
\hline $\mathrm{C}_{1} 6$ & $0.8 \mathrm{~b}$ & 14 & $3 \mathrm{bx}$ & $67 \mathrm{cy}$ & $17 \mathrm{ax}$ & 35 by \\
\hline$P_{1} 6$ & $0.3 \mathrm{a}$ & 3 & $\mathrm{NI}$ ax & $62 \mathrm{cy}$ & 13 ax & $44 \mathrm{cy}$ \\
\hline
\end{tabular}

${ }^{a}$ Extent of hydrolysis is expressed as the milliequivalents of leucine per gram of dried gelatin.

${ }^{b}$ The solid that was recovered after ultrafiltration through the $3 \mathrm{kDa}$ membranes, as a percentage of the starting gelatin weight.

${ }^{\mathrm{c}} \mathrm{ACE}$ inhibitory activity was determined at a final sample concentration of $0.286 \mathrm{mg} / \mathrm{ml}$; $\mathrm{NI}$ indicates no detectable inhibitory activity.

${ }^{\mathrm{d} D P P}-\mathrm{IV}$ inhibitory activity was determined at a final sample concentration of $0.5 \mathrm{mg} / \mathrm{ml}$.

${ }^{e}$ Different letters $(a, b, c, d, e)$ indicate significant difference at $p<0.05$ within the column while different letters $(x, y)$ indicate significant difference at $p<0.05$ of inhibitory activity between each unfractionated ("whole") hydrolysate and its $<3$ kDa fraction. 
Table 3. Extent of hydrolysis (EH), angiotensin-I converting enzyme (ACE) inhibitory activity and dipeptidyl-peptidase IV (DPP-IV) inhibitory activity of steelhead gelatin hydrolysates prepared using sequential pepsin (P)-CorolaseN (C) or CorolaseN (C)-pepsin (P) hydrolysis.

\begin{tabular}{|c|c|c|c|c|c|c|c|c|c|c|c|c|}
\hline \multirow[b]{2}{*}{ Sample ${ }^{a}$} & \multicolumn{4}{|c|}{ EH (meq Leu/g) } & \multicolumn{4}{|c|}{ ACE Inhibition (\%) } & \multicolumn{4}{|c|}{ DPP-IV Inhibition (\%) ${ }^{\text {de }}$} \\
\hline & $0 \mathrm{hr}$ & $3 \mathrm{hr}$ & $6 \mathrm{hr}$ & $12 \mathrm{hr}$ & $0 \mathrm{hr}$ & $3 \mathrm{hr}$ & $6 \mathrm{hr}$ & $12 \mathrm{hr}$ & $0 \mathrm{hr}$ & $3 \mathrm{hr}$ & $6 \mathrm{hr}$ & $12 \mathrm{hr}$ \\
\hline$P_{1} 3 C_{1} 3$ & 0.069 ax & 0.27 ay & $0.81 \mathrm{bz}$ & NA & $\mathrm{NI}$ ax & $\mathrm{NI}$ ax & 21 by & NA & 12 ax & $12 \mathrm{ax}$ & 23 by & NA \\
\hline$P_{1} 6 C_{1} 6$ & 0.011 ax & NA & 0.26 ay & $0.69 \mathrm{az}$ & $\mathrm{NI}$ ax & NA & $\mathrm{NI}$ ax & 22 ay & 9 ax & NA & 13 ax & 22 ay \\
\hline $\mathrm{C}_{1} 3 \mathrm{P}_{1} 3$ & $0.26 \mathrm{bx}$ & 0.80 by & 0.83 by & NA & $\mathrm{NI}$ ax & 24 by & 24 bcy & NA & $19 \mathrm{bx}$ & 23 bxy & 25 by & NA \\
\hline $\mathrm{C}_{1} 6 \mathrm{P}_{1} 6$ & $0.25 \mathrm{bx}$ & NA & 0.79 by & 0.75 ay & $\mathrm{NI}$ ax & NA & $26 \mathrm{cy}$ & 29 by & $18 \mathrm{bx}$ & NA & $22 \mathrm{bx}$ & 37 by \\
\hline
\end{tabular}

${ }^{a}$ The sample codes used can be deciphered as follows: the first letter represents the enzyme used in the initial hydrolysis, with accompanying subscript number indicating 1\% of that enzyme was used in the hydrolysis and the next number indicating the duration ( 3 or 6 hrs) of the hydrolysis; the second letter represents the second enzyme used for subsequent hydrolysis, with subscript number and the next number indicating respectively that $1 \%$ of the enzyme was used for an additional 3 or 6 hrs of hydrolysis.

${ }^{b}$ Extent of hydrolysis is expressed as the milliequivalents of leucine per gram of dried gelatin.

${ }^{\mathrm{C}} \mathrm{ACE}$ inhibitory activity was determined at a final sample concentration of $0.286 \mathrm{mg} / \mathrm{ml}$; NI indicates no detectable inhibitory activity and NA indicates no analysis performed at the time point.

${ }^{d}$ DPP-IV inhibitory activity was determined at a final sample concentration of $0.5 \mathrm{mg} / \mathrm{ml}$; NA indicates no analysis performed at the time point.

${ }^{e}$ Different letters $(a, b, c)$ indicate significant difference at $p<0.05$ among different samples at the same time point while different letters $(x, y, z)$ indicate significant difference at $p<0.05$ between different time points of the same hydrolysis. 
Table 4. Angiotensin-I converting enzyme (ACE) and dipeptidyl-peptidase IV (DPP-IV) inhibitory activity of steelhead gelatin hydrolysates, and their $<3 \mathrm{kDa}$ ultrafiltration fractions, prepared using Protease $P$ "Amano" 6SD (A), Protease M “Amano" SD (M), bromelain (B), Alcalase (L), papain (Pa), pepsin (P), and CorolaseN (C).

\begin{tabular}{|c|c|c|c|c|c|}
\hline \multirow[b]{2}{*}{ Sample ${ }^{a}$} & \multirow{2}{*}{$\begin{array}{c}\text { Solid } \\
\text { Recovery in } \\
<3 \mathrm{kDa} \\
\text { fraction }(\%)^{\mathrm{b}}\end{array}$} & \multicolumn{2}{|c|}{ ACE Inhibition (\%) ${ }^{c}$} & \multicolumn{2}{|c|}{ DPP-IV Inhibition (\%) } \\
\hline & & Unfractionated $^{\mathrm{e}}$ & $<3 \mathrm{kDa}^{\mathrm{e}}$ & Unfractionated $^{\mathrm{e}}$ & $<3 \mathrm{kDa}^{\mathrm{e}}$ \\
\hline$A_{4} 2$ & 51 & $25 \mathrm{abx}$ & 54 by & 23 ax & $22 \mathrm{ax}$ \\
\hline $\mathrm{M}_{4} 2$ & 37 & $27 \mathrm{bx}$ & 57 bcy & 19 ax & 21 ay \\
\hline $\mathrm{B}_{4} 2$ & 30 & 19 ax & 59 bcy & $33 \mathrm{bcx}$ & $39 \mathrm{bx}$ \\
\hline $\mathrm{L}_{4} 2$ & 37 & 19 ax & 22 ax & $26 \mathrm{abx}$ & 23 ay \\
\hline $\mathrm{Pa}_{4} 2$ & 54 & $29 b x$ & 54 by & $45 d x$ & 42 cy \\
\hline $\mathrm{C}_{1} 6 \mathrm{P}_{1} 6$ & 32 & $29 \mathrm{bx}$ & $63 \mathrm{cy}$ & $35 \mathrm{cx}$ & $44 \mathrm{cy}$ \\
\hline
\end{tabular}

${ }^{a}$ The sample codes used can be deciphered as follows: the first letter represents the enzyme used for hydrolysis, with accompanying subscript number indicating that either 1 or $4 \%$ of that enzyme was used in the hydrolysis and the next number indicating the duration ( 2 or $6 \mathrm{hrs}$ ) of the hydrolysis. For $\mathrm{C}_{1} 6 \mathrm{P}_{1} 6$, the second letter $P$ represents the second enzyme used for subsequent hydrolysis, with subscript number and the next number indicating respectively that $1 \%$ of the second enzyme was used for an additional 6 hrs of hydrolysis.

${ }^{b}$ The solid that is recovered after ultrafiltration through the $3 \mathrm{kDa}$ membranes, as a percentage of the starting gelatin weight.

${ }^{c} A C E$ inhibitory activity was determined at a final sample concentration of $0.286 \mathrm{mg} / \mathrm{ml}$.

${ }^{\mathrm{d} D P P}-\mathrm{IV}$ inhibitory activity was determined at a final sample concentration of $0.5 \mathrm{mg} / \mathrm{ml}$.

${ }^{e}$ Different letters $(a, b, c, d)$ indicate significant difference at $p<0.05$ within the column while different letters $(x, y)$ indicate significant difference at $p<0.05$ of inhibitory activity between unfractionated hydrolysate and its $<3 \mathrm{kDa}$ fraction. 


\section{Figure Captions}

Figure 1. Extent of hydrolysis of steelhead gelatin hydrolysates prepared by incubation for 2 or $6 \mathrm{hrs}$ with $1 \%$ or $4 \%(\mathrm{w} / \mathrm{w} \mathrm{E} / \mathrm{S})$ of one of the five enzymes individually, or with a subsequent 2 hr hydrolysis with $1 \%$ of either CorolaseN (C) or pepsin (P). An asterisk above the bar indicates significant difference at $p<0.05$ incurred by $P$ or $C$ within each group.

(a) Protease P “Amano" 6SD ( $A, A+P, A+C)$; (b) Protease M “Amano" SD (M, $M+P, M+C)$; (c) bromelain (B, $B+P, B+C)$; (d) Alcalase $(L, L+P, L+C)$; (e) papain $(\mathrm{Pa}, \mathrm{Pa}+\mathrm{P}, \mathrm{Pa}+\mathrm{C})$.

Figure 2. Angiotensin-I converting enzyme (ACE) inhibitory activity of steelhead gelatin hydrolysates prepared by incubation for 2 or $6 \mathrm{hrs}$ with $1 \%$ or $4 \%$ (w/w E/S) of one of the five enzymes individually, or with a subsequent $2 \mathrm{hr}$ hydrolysis with $1 \%$ of either CorolaseN (C) or pepsin (P). An asterisk above the bar indicates significant difference at $\mathrm{p}<0.05$ incurred by $\mathrm{P}$ or $\mathrm{C}$ within each group. $\mathrm{NI}$ indicates no detectable activity for the sample.

(a) Protease $P$ "Amano" 6SD ( $A, A+P, A+C)$; (b) Protease M “Amano" SD ( $M, M+P, M+C)$; (c) bromelain ( $B$, $\mathrm{B}+\mathrm{P}, \mathrm{B}+\mathrm{C})$; (d) Alcalase $(\mathrm{L}, \mathrm{L}+\mathrm{P}, \mathrm{L}+\mathrm{C})$; (e) papain $(\mathrm{Pa}, \mathrm{Pa}+\mathrm{P}, \mathrm{Pa}+\mathrm{C})$.

Figure 3. Dipeptidyl peptidase IV (DPP-IV) inhibitory activity of steelhead gelatin hydrolysates prepared by incubation for 2 or 6 hrs with $1 \%$ or $4 \%$ (w/w E/S) of one of the five enzymes individually, or with a subsequent $2 \mathrm{hr}$ hydrolysis with $1 \%$ of either CorolaseN (C) or pepsin (P). An asterisk above the bar indicates significant difference at $\mathrm{p}<0.05$ incurred by $\mathrm{P}$ or $\mathrm{C}$ within each group.

(a) Protease P "Amano" 6SD ( $A, A+P, A+C)$; (b) Protease M "Amano" SD ( $M, M+P, M+C)$; (c) bromelain (B, $B+P, B+C)$; (d) Alcalase $(L, L+P, L+C)$; (e) papain $(P a, P a+P, P a+C)$. 

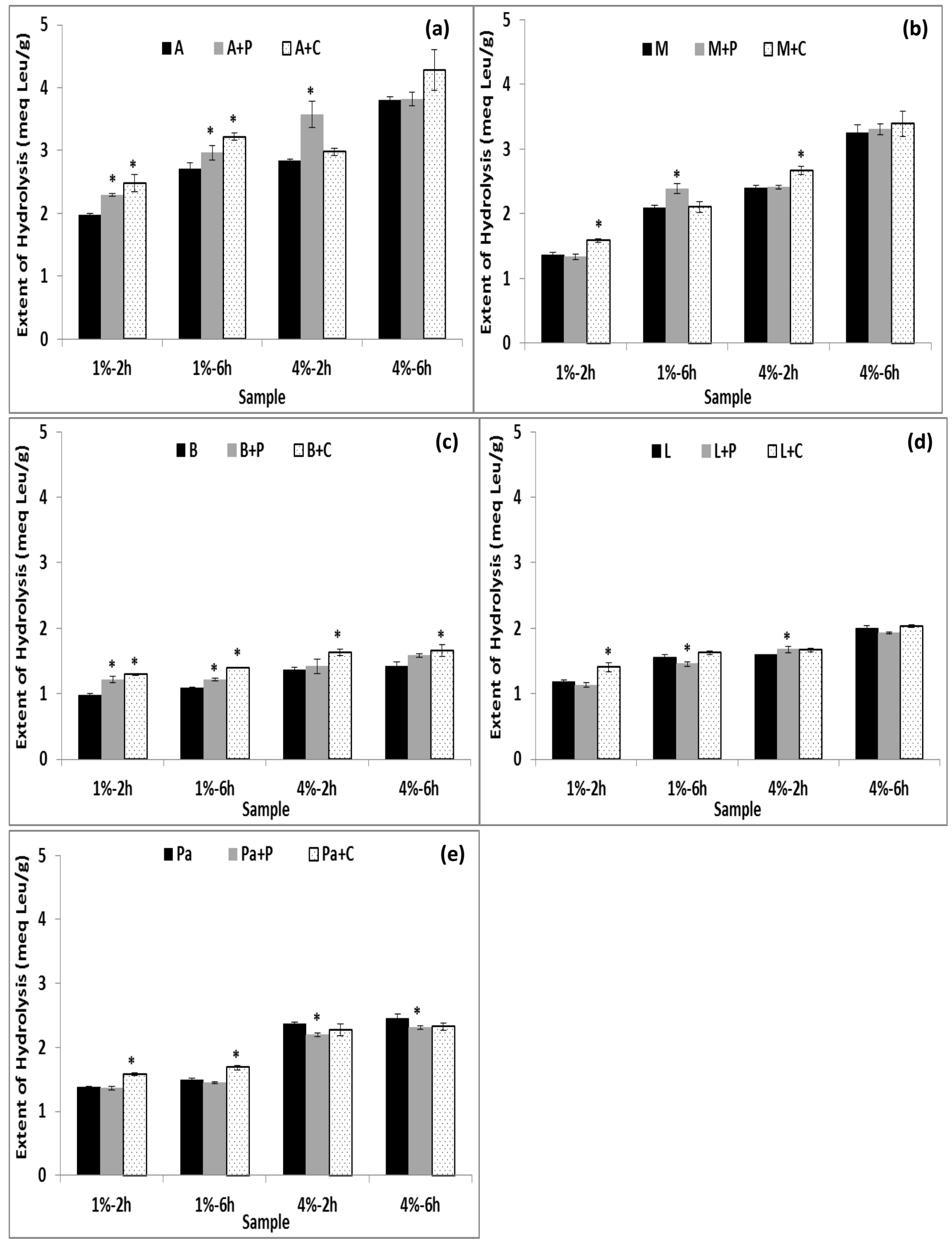

Figure 1. 


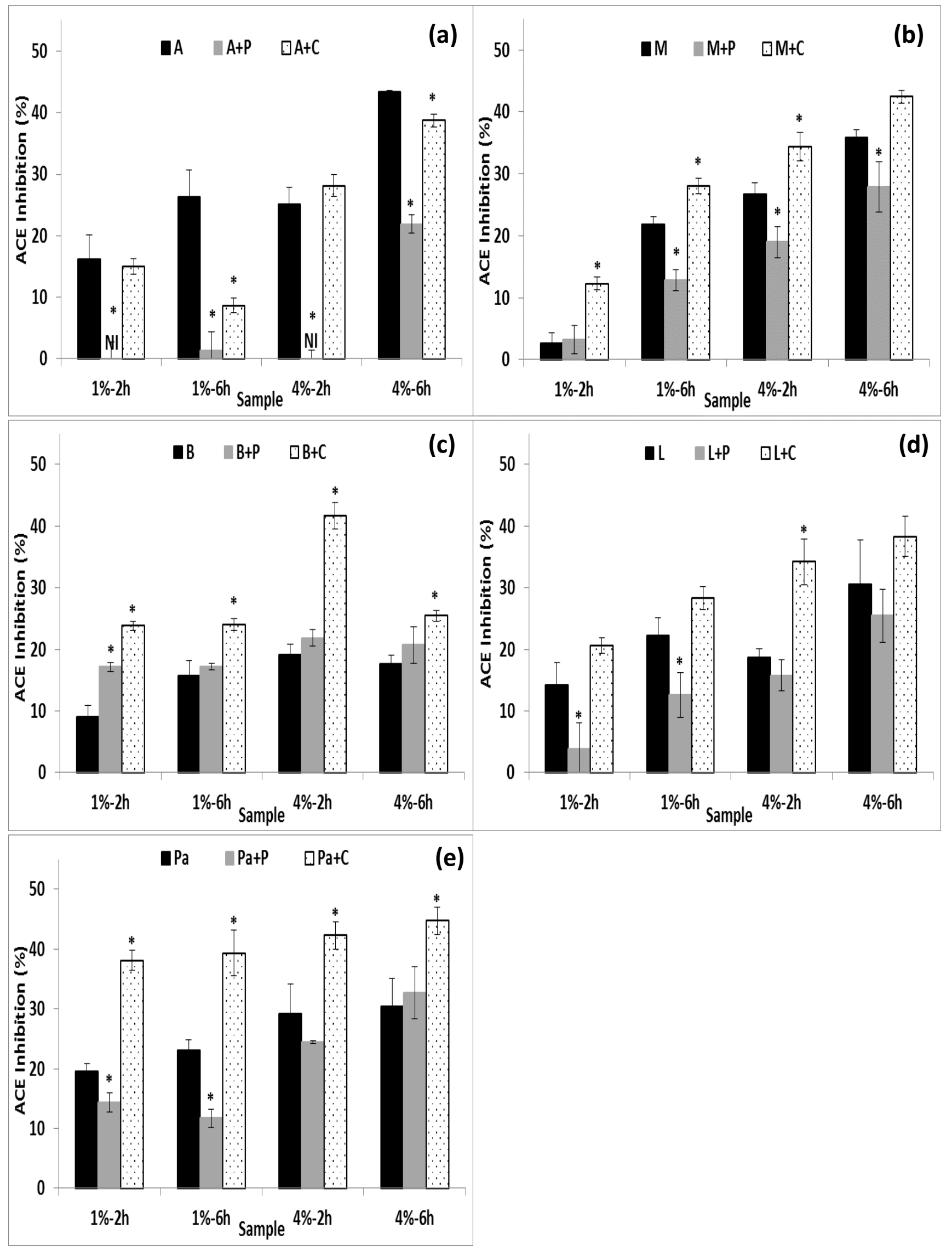

Figure 2. 

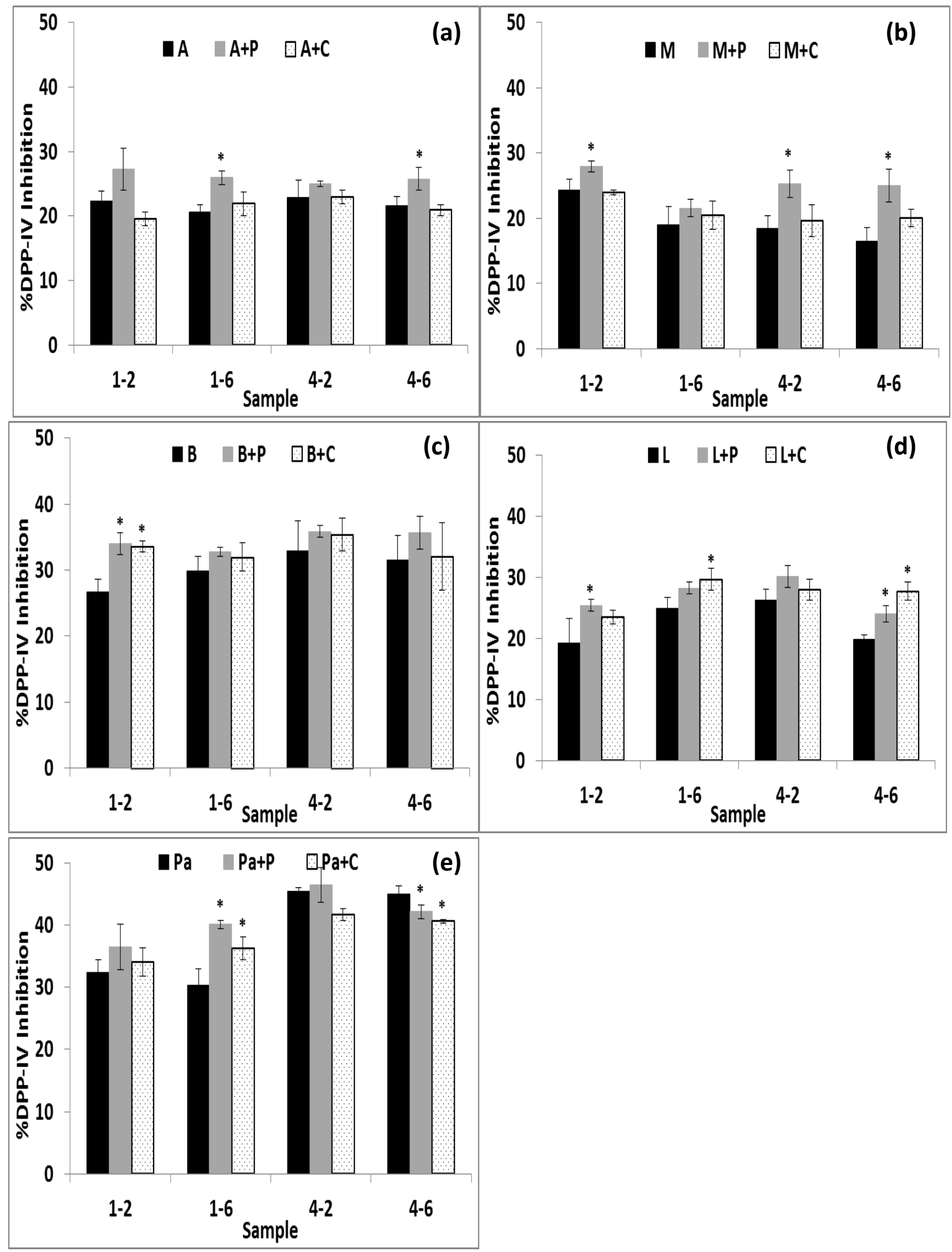

Figure 3. 